\title{
FORUM
}

\section{Discovery and Development of Biological Agents to Control Crop Pests}

\author{
Patricia J. Slininger, Robert W. Behle, Mark A. Jackson and David A. Schisler \\ National Center for Agricultural Utilization Research, United States Department of Agriculture, Agricultural Research \\ Service, 1815 N. University Street, Peoria, Illinois, 61604-3902, USA
}

Neotropical Entomology 32(2):183-195 (2003)

Descoberta e Desenvolvimento de Agentes de Controle Biológico de Pragas de Culturas

\begin{abstract}
RESUMO - Milhares de agentes de controle microbiano potenciais têm sido isolados a partir de campos cultivados ou de culturas pelo esforço da pesquisa nos últimos 80 anos. Entretanto, apenas alguns microrganismos têm uso comercial. Recentemente, medidas de saúde pública e de segurança sobre o impacto ambiental de pesticidas químicos têm levado a se considerar o controle biológico como uma medida promissora para proteção das culturas. Apesar do incentivo ambiental e esforços de pesquisa, a evolução da comercialização dos agentes de biocontrole tem sido lenta. O "momentum" da indústria química é difícil de mudar, e processos fermentativos tendem a ser mais caros e custosos do que os processos químicos sintéticos. Mesmo assim, há demanda para produtos de controle biológico, especialmente em nichos de mercados agrícolas onde não existe um competidor químico. Entretanto, os fundamentos dos métodos econômicos de produção e aplicação dos agentes de biocontrole em larga escala não existem. Muitos aspectos do desenvolvimento e da produção de agentes de controle biológico representam uma área diferenciada na tecnologia de produção industrial por fermentação, já bem estabelecida no nicho farmacêutico e alimentar. Ao se diferenciar dos produtos fermentados tradicionais, os agentes de biocontrole necessitam atingir os critérios de alta (ca. 100\%) retenção da viabilidade celular e compatibilidade com a cultura e bioeficiência durante vários meses de armazenagem. Exemplos da pesquisa são discutidos exemplificando-se os desafios e as estratégias dos processo de desenvolvimento para produzir e viabilizar agentes de biocontrole de insetos, ervasdaninhas e doenças.
\end{abstract}

PALAVRAS-CHAVE: Biopesticida, controle biológico, fermentação, formulação, estabilização

ABSTRACT - Thousands of potential microbial biocontrol agents have been isolated from agricultural fields and crops during research over the last 80 years, yet only a few are in commercial use. Recently, public health and safety concerns about the environmental impact of chemical pesticides have led to consideration of biological control as a natural approach to maintaining crop health. Despite environmental incentives and strong research efforts, commercialization of biocontrol agents has been slow to evolve. The momentum of the chemical industry is difficult to shift, and fermentation processes tend to be more expensive to operate than synthetic chemical processes. Yet there is a demand for biological control products, especially in agricultural niche markets, where there is no chemical competitor. However, given this market demand, the fundamental methods of economical large-scale production and application of biological control agents are lacking. Many aspects of biocontrol agent production and development represent untrodden territory in the progression of industrial fermentation technology beyond its well-established food and pharmaceuticals niche. Distinguishing them from traditional fermentation products, biocontrol agents must not only be produced in high yield but must also meet the following quality criteria: high (near 100\%) retention of cell viability with maintenance of crop compatibility and consistent bioefficacy during several months of storage. Research examples will be reviewed to illustrate the challenges and strategies of developing processes to manufacture and deliver biological agents for insect, weed, and plant disease control.

KEY WORDS: Biopesticide, biological control, fermentation, formulation, stabilization 
Commercial biopesticides must be economical to produce, have persistent storage stability, have adequate field persistence, be easy to handle, mix, and apply, and provide consistently effective control of the target pest or group of pests. The ultimate goal of biological control agent research and development is to arrive at the biotechnologies needed to produce biologicals that will effectively compete with chemicals; but for the present, market success is most likely to occur if the biological is developed to combat pest problems which have no chemical pesticide solution or which exist in situations where chemical applications are prohibited. For example, in the U.S. organic farming is the fastest growing sector of agriculture. Higher commodity prices for these products and regulations restricting the use of chemical pesticides improve the chances for successful commercialization in these markets (Behle et al. 1999). Once effectiveness is established in this sector of production, the transition to other sectors could follow.

A major benefit of developing biopesticides is the ease of federal registration. The Environmental Protection Agency (EPA) has established a Biopesticide Pollution and Prevention Division (BPPD) to manage accelerated registration of biopesticides. In the mid 1990's, the average duration for registration of a biopesticide was 12 months compared with 36 months for all new chemical pesticide registrations (Medugno et al.1997), and the cost of registration of a chemical was often more than eight times that of a biological (Woodhead et al. 1990).

Despite regulatory incentives, relatively few biological control agents have reached the market place. Some reasons for this are seen in an analysis of the basic steps to commercialization of a new microbial pest control agent as outlined in Fig. 1 (Jackson 1997). In the discovery phase, the first steps are to isolate and identify microbes that are economically produced, that aggressively suppress a target pest population, and that do not harm the crop or non-target organisms. In the next steps, microbial cultivation and formulation techniques must be developed to minimize product cost and maximize yield and quality. Quality factors include pest control efficacy, stability through drying and storage, host compatibility, and adequate field persistence. Once technologies are in place to economically

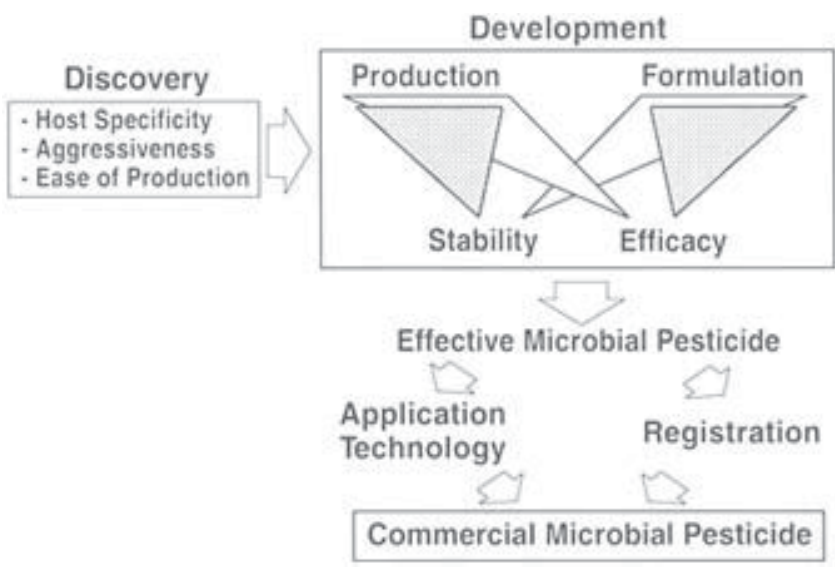

Figure 1. Steps to commercialization of a new microbial pest control agent (Jackson 1997). produce an effective microbial pesticide, then the final steps of application and registration can be pursued to allow marketing of the new microbial pesticide. Successful commercialization hinges on the outcome of the development process and is often limited by a lack of knowledge of and experience with biological control agent production and formulation techniques.

Over the past decade, our research group has focused on closing this technology void. Since batch liquid cultivation of microbial products is an industrial standard in the United States, we have used this process as a screen for selecting commercially viable strains and have studied how its design can be used to maximize biocontrol product yield and quality. Novel formulation strategies have also been designed to maximize stored product stability and performance upon delivery to the crop.

\section{Selecting Commercially Viable Biocontrol Strains}

The fact that such a small proportion of laboratory antagonists are developed into commercial biological control products is partly due to several features common to microbial selection strategies that are widely utilized: (a) the choice of pathosystem for biological control is poor; (b) relatively few candidate microorganisms are tested; (c) microbes are selected based on the results of an assay that does not replicate field conditions; and (d) the amenability of microbes to commercial development is excluded as a selection criterion. To illustrate how and why to avoid these pitfalls in critical early stages of biocontrol product development, our experience on selecting bacterial strains for the biological control of Fusarium dry rot, an important postharvest disease of potatoes, will be reviewed below (Schisler \& Slininger 1994, Slininger et al. 1994, Schisler \& Slininger 1997, Schisler et al. 1998).

Choice of Pathosystem. A pest problem that is commercially manageable by biological control would have many of the following characteristics: an exploitable pathogen etiology, existence in an environment favoring biocontrol agent colonization, resistance to traditional pest control strategies, and the capability to cause significant crop loss. Regarding disease pathosystems, we chose to develop microbial agents active against Fusarium dry rot caused by Gibberella pulicaris (Fr.:Fr.) Sacc. (anamorph: Fusarium sambucinum Fuckel) in stored potato tubers. A major weakness of the etiology of this pathogen is that it requires a wound in order to infect, and tubers are able to heal wounds in less than two weeks. Additionally, the pathogen operates in tuber storage houses where cool temperatures and high humidity $(>90 \%)$ favor the competitive colonization of bacterial antagonists that suppress disease progression in wounds. Thiabendazole resistance in field populations of G. pulicaris have rendered this fungicide of little use in protection of potato storages. The complete lack of other chemical fungicides for application to potatoes stored for food use make the development of biological products to control dry rot an attractive option. In any given year in North America, storage losses to dry rot average from $6 \%$ to $25 \%$ (Chelkowski 1989), and since $70 \%$ of the potato crop is stored (representing an investment of $\$ 1.4$ billion), the 
potential annual loss averages $\sim \$ 84-\$ 380$ million (Slininger $e t$ al. 2000). In addition to destroying tuber tissues, G. pulicaris can produce trichothecene toxins that have been implicated in mycotoxicosis of humans and animals, so the potential for damage is high enough to justify the economic risk of developing a biological control agent.

Rapid Isolation from Large Populations. Biological control agent isolation should begin in areas where they naturally occur. Evaluating a maximal number of putative biocontrol agents increases the chance of discovering an effective strain. Isolating prospective biocontrol agents from appropriate tissues and under appropriate environmental conditions helps to insure that the microbial antagonists isolated will be well adapted to survival and activity on the specific tissues requiring protection. Application of these concepts resulted in our rapid isolation of 18 putative biological control agents for suppression of Fusarium dry rot. In our method (Fig. 2), gamma irradiation-sterilized field soil samples were enriched with potato tuber periderm, inoculated with a small amount of field soil obtained from potato fields with little dry rot disease incidence and incubated for one week at $15^{\circ} \mathrm{C}$. The microorganisms most adept at rapid growth on the nutrients found in potato periderm and at wound sites would make up the majority of microbes in each recolonized soil sample. Conidia of $G$. pulicaris were then added to the microbially recolonized soils, and two days later, aqueous soil pastes of each soil were applied to wounded potato tubers. After incubation four weeks at $15^{\circ} \mathrm{C}$, tubers were scored for dry rot disease development. Those wounds that developed inconsequential disease were highly likely to contain microbial communities able to survive on potato periderm and colonize potato tissue to suppress disease development. Consequently, clear wounds were excavated and dilution plated on nonselective media that allowed growth of bacteria, fungi, actinomycetes, and yeasts to allow isolation of the broadest possible microbial diversity for exploitation. Using this process, over 350 isolated bacterial colonies were obtained from clear wounds receiving microbial communities transferred via live soil samples from 35 locations of low disease incidence. To screen out only those strains participating in dry rot suppression, each isolate was suspended in buffer with conidia of the pathogen and inoculated to a fresh potato wound. After three weeks at $15^{\circ} \mathrm{C}$, tubers were checked for the presence of disease and only 18 of the 350 isolates demonstrated significant dry rot suppression relative to controls inoculated only with pathogen.

Realistic Bioassay to Assess Commercial Potential. In order to focus further development on strains most likely to succeed in the market place, it is necessary to design a realistic bioassay that mimics commercial production and application settings such that strains can be evaluated and selected based on their performance under conditions simulating key industrial challenges. Since the U.S. industry standard for the manufacture of microbial products is batch liquid cultivation, this was chosen as the method of producing the eighteen dry rot antagonistic bacteria for further evaluations.

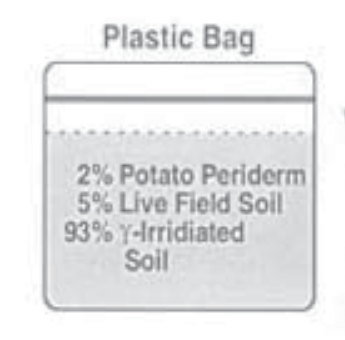

Enrich Periderm Colonists
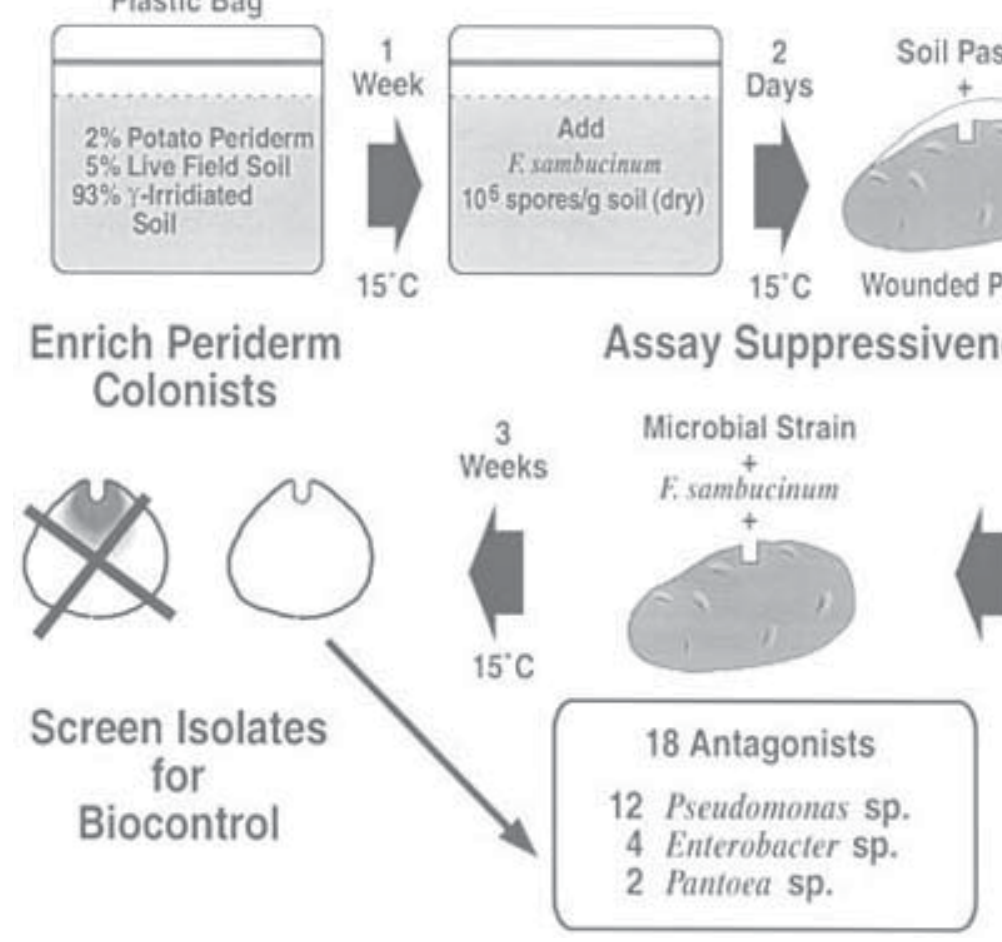
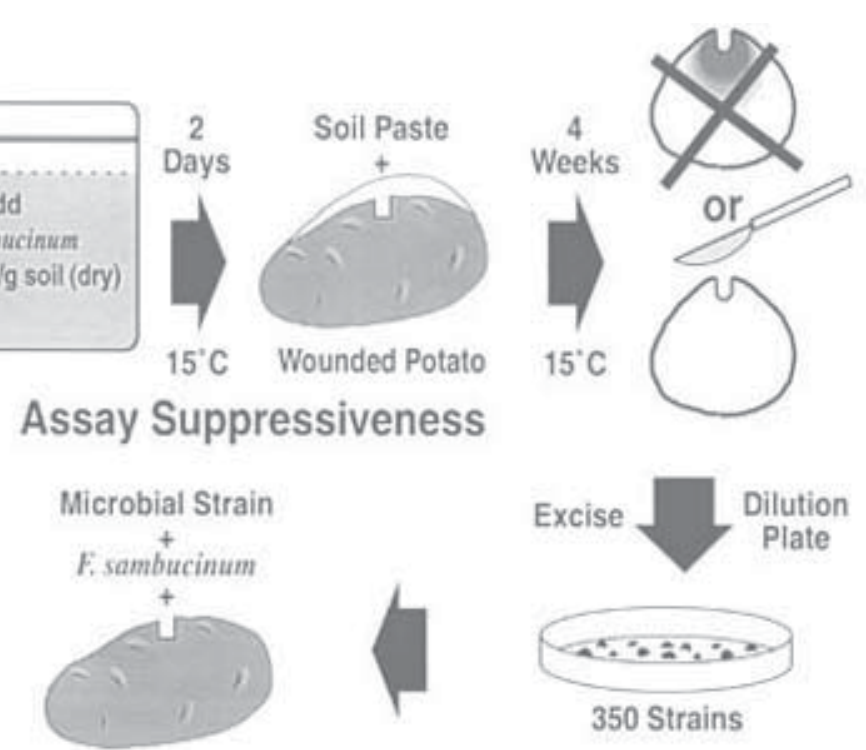

Isolate

Colonists of

Healthy

Wounds

Figure 2. Isolation of microbial antagonists effective in suppressing Fusarium dry rot of potatoes (Schisler \& Slininger 1994, 1997). 
Compared with synthetic chemical processes, fermentation processes are relatively expensive, a circumstance which has largely limited the development of biotechnology to the food and pharmaceutical fields.

Primary fermentation cost factors include raw materials, utilities, labor, and capital investment, and so our bioassay was designed to screen for strains that would minimize these costs. First, our selection of the strains was based on their ability to grow rapidly and to high yield on a variety of liquid culture media and then to accomplish biocontrol upon harvest and delivery to potatoes. These considerations were combined to select efficacious dry rot antagonists that could be produced with reduced fermentor volume and processing time costs. In addition, strains with nutritional flexibility to grow rapidly and achieve large bioefficacious populations were sought by challenging with glucose media ranging in richness from a minimal medium (with nitrogen supplied by urea) to a semidefined complete medium (with casamino acids and growth factors) to an undefined medium (with added yeast extract, peptone, and tryptone). Consistent with minimizing utilities costs, shake-flask cultures used to screen strains were provided a low oxygen transfer coefficient $\left(\mathrm{K}_{1} \mathrm{a} \sim 0.5 \mathrm{~min}^{-1}\right)$ and moderate temperature $\left(25^{\circ} \mathrm{C}\right)$. Finally, harvested bacteria were then bioassayed using the wounded potato assay described above to assess efficacy.

For each bacterium, a relative performance index (RPI) was calculated based on each kinetic parameter, such as cell yield and specific growth rate. Given parameter values normally distributed across the isolate group tested, the value of $\mathrm{F}=(\mathrm{X}$ $\left.\mathrm{X}_{\mathrm{avg}}\right)$ /s ranges from -2 to +2 . Here, $\mathrm{X}$ designates a single value observed per bacterium, and $\mathrm{X}_{\mathrm{avg}}$ and $\mathrm{s}$ are the average and standard deviation, respectively, of all values observed for the isolate group. Using the formula RPI $=(F+2) \times 100 / 4$, data corresponding to each parameter type were translated to dimensionless indices, scaled from 0 to 100 , which reflected relative bacterial performance. For a given production trial, overall relative kinetic performance indices were calculated for each bacterium: $\mathrm{RPI}_{\text {kinetics }}=\left(\mathrm{RPI} \mathrm{I}_{\text {growth rate }}+\mathrm{RPI}_{\text {cell vield }}\right) / 2$. Similarly, a relative performance index based on biocontrol efficacy was calculated for each bacterium using log (disease rating) data: $\mathrm{RPI}_{\text {efficacy }}=(2-\mathrm{F}) \times 100 / 4$. Note that the term $(2-\mathrm{F})$ is used instead of $(2+\mathrm{F})$ because efficacy improves as disease rating decreases. Thus, RPI efficacy $_{\text {and }} \mathrm{RPI}_{\text {kinetics }}$ are provided a common dimensionless 0 to100 scale that allows both data types equal weight in the overall performance assessment. As a result of this screening method (Fig. 3), referred to as "two-dimensional liquid culture focusing (2DLCF)," six of the eighteen bacterial dry rot antagonists were identified as having highest potential for commercial development (Table 1, Fig. 4A).

Dogma calls for screening the efficacies of prospective biocontrol agents grown under conditions as similar as possible to what is expected to be encountered in nature. Thus, "promising" isolates have been traditionally selected based on efficacy following growth on solidified media. Only after extensive laboratory, greenhouse and field tests of these promising isolates has mass production in liquid culture become a concern. Indeed our data have shown that the traditional onedimensional screen based on bioefficacy of agar-grown isolates selects a different set of top-performers than does the commercial process-oriented 2DLCF screen. Also, the traditional screen is likely to miss selection of the most commercially useful biocontrol agents because it fails to recognize that liquid culture competency varies widely among microbes. Our experiments have illustrated this by showing that the top-performing strains selected via the 2DLCF screen were often the worst performing strains in the traditional onedimensional screen of agar-grown isolates (Table 2). If our goal is to develop bacteria with a commercial future as biocontrol agents, then early screening strategies must reflect the production requirements of the commercial setting. Since liquid culture is the industrial standard for microbial production, liquid cultivation should be the method of biocontrol agent production during early screening. In addition, a twodimensional assay examining liquid culture growth kinetics as well as product biocontrol efficacy is needed, because our results have shown that isolate performance ranking based on kinetics does not necessarily reflect the performance ranking based on the biocontrol efficacy.

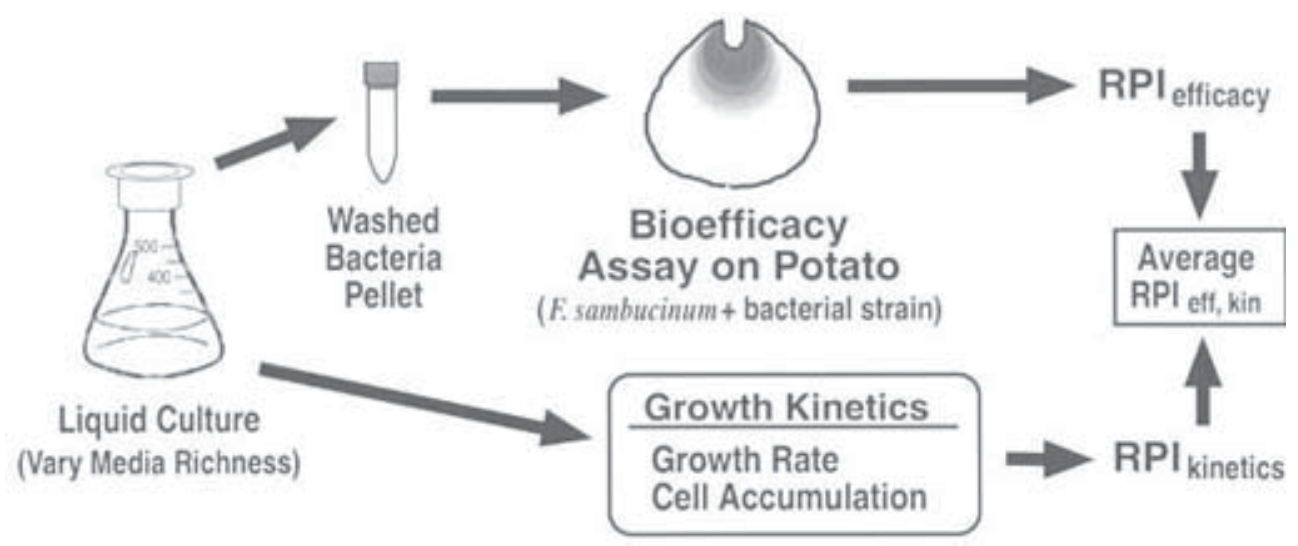

Figure 3. Two-dimensional liquid culture focusing method of objectively ranking the commercial development potentials of microbial strains based on relative performance indices (RPI) calculated from the strains' growth kinetics and efficacy when produced in liquid culture. RPI's are dimensionless indices with values between 0 and 100 (best performance) when data are normally distributed (Slininger et al. 1994, Schisler \& Slininger 1994). 
Multi-Dimensional Screens to Assess Commercial Potential. The concept of early commercial-process-oriented screening brings us closer to rapid development of marketable biocontrol agents; however, it is likely that liquid cultivation of biocontrol agents will be followed by formulation, drying, storage, and reconstitution prior to potato application. These steps are necessary to preserve cells for convenient storage and handling in the time between production and application, and represent other features or "challenges" that could be built into an expanded multi-dimensional strategy for selecting the most commercially promising strains. The ability of biocontrol agents to solve multiple pest control problems is another potential screening

Table 1. Use of relative performance indices (RPI) to accomplish a two-dimensional assessment of isolate commercial potential based on growth and efficacy of cells produced in liquid culture (Slininger et al. 1994).

\begin{tabular}{lcccc}
\hline \multirow{2}{*}{$\begin{array}{l}\text { Isolate number } \\
\text { (NRRL-) }\end{array}$} & \multicolumn{2}{c}{ RPI $^{1}$} & Overall $^{2}$ RPI $_{\text {Eff.Kin }}$ & $\begin{array}{c}\text { Commercial }^{2} \\
\text { potential group }\end{array}$ \\
\cline { 2 - 3 } B-21050 & Efficacy & Growth kinetics & & A \\
B-21128 & 67.3 & 65.0 & $66.2 \pm 4.9$ & A \\
B-21133 & 66.3 & 64.9 & $65.6 \pm 5.6$ & A \\
B-21134 & 67.2 & 62.3 & $64.8 \pm 3.6$ & A \\
B-21132 & 66.3 & 60.3 & $63.3 \pm 4.4$ & AB \\
B-21102 & 56.9 & 69.4 & $63.1 \pm 5.6$ & ABC \\
B-21136 & 62.1 & 60.8 & $61.4 \pm 7.4$ & BC \\
B-21101 & 58.9 & 57.6 & $58.2 \pm 6.9$ & BC \\
B-21103 & 56.9 & 58.8 & $57.9 \pm 4.9$ & C \\
B-21053 & 58.4 & 55.7 & $57.0 \pm 4.4$ & C \\
B-21135 & 59.2 & 54.2 & $56.7 \pm 5.7$ & CD \\
B-21129 & 58.7 & 53.8 & $56.2 \pm 6.0$ & DE \\
B-21104 & 53.0 & 56.5 & $55.1 \pm 11.6$ & DE \\
B-21048 & 63.2 & 35.9 & $49.5 \pm 10.5$ & DE \\
B-21137 & 47.1 & 45.4 & $46.2 \pm 11.1$ & E \\
B-21051 & 42.8 & 46.7 & $44.7 \pm 11.5$ & F \\
B-21105 & 60.9 & 25.1 & $43.0 \pm 12.2$ & F \\
B-21049 & 38.4 & 28.3 & $33.3 \pm 7.1$ & $27.5 \pm 9.6$ \\
\hline
\end{tabular}

${ }^{1} \mathrm{RPI}_{\mathrm{Efficacy}}$ and $\mathrm{RPI}_{\text {Kinetics }}$ each indicate the average of six RPI values determined from two independent productions of cells on minimal defined, semi-defined, and undefined liquid media.

${ }^{2}$ Commerical potential groupings were arrived at by applying a two-tailed $t$ analysis to determine the $95 \%$ confidence intervals associated with each mean $\mathrm{RPI}_{\mathrm{Eff}, \mathrm{Kin}}$ as indicated by \pm values. Means that are not significantly different are designated with the same group letter.
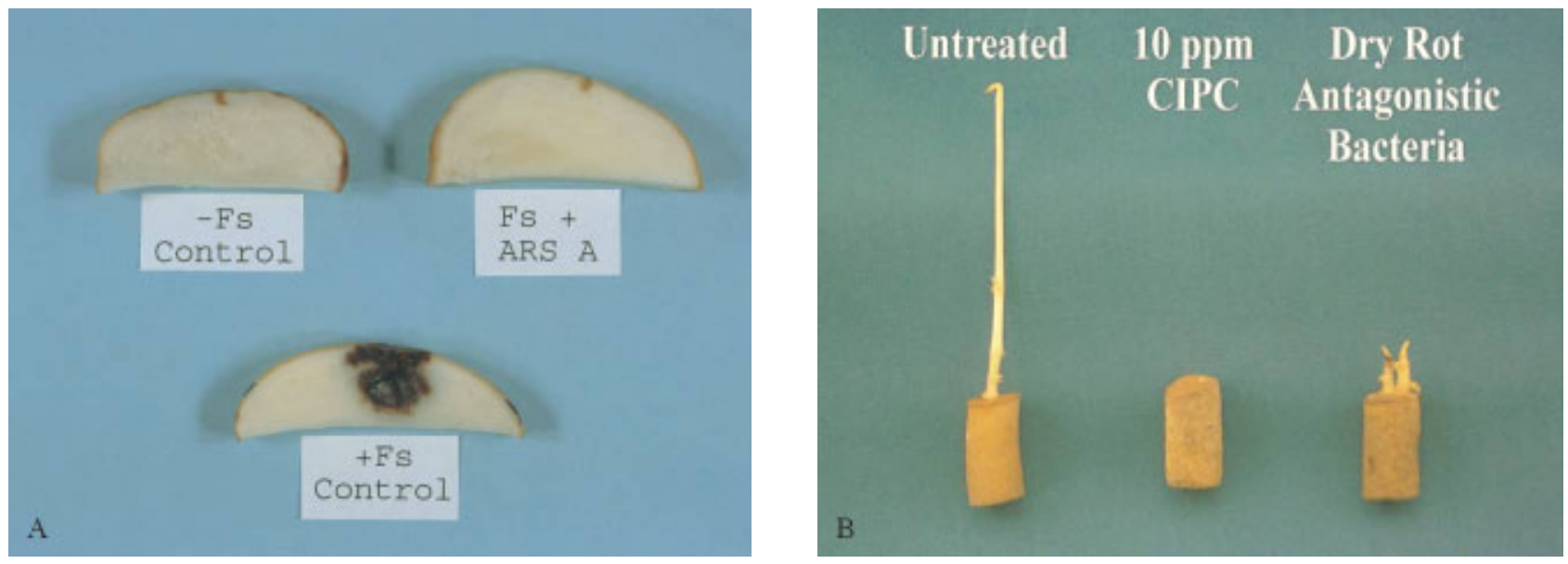

Figure 4. A. Biological control of Fusarium dry rot disease by a bacterial strain (ARS A) characterized as being in commercial potential group A using the 2DLCF assay. Disease suppression by strain ARS A is shown relative to controls in which potato wounds were inoculated with only the pathogen F. sambucinum (bottom) or with sterile buffer solution only (top left). B. Biological control of sprouting by commercial potential group A dry rot antagonistic bacteria (right) shown relative to controls in which potato eye corings were treated with nothing (left) or with 10 ppm CIPC (center), a chemical sprout inhibitor used worldwide. 
dimension. For example, our dry rot antagonistic bacteria have also been shown to be able to suppress sprouting of stored potatoes (Fig. 4B) (Slininger et al. 2000). Furthermore, the mycoinsecticide Paecilomyces fumosoroseus (Pf) has been shown to be an effective biological control agent of silver leaf whitefly Bemisia argentifolii (Jackson et al. 1997, Jackson 1997) and Russian wheat aphid Diuraphis noxia (Kurdjumov) (Vandenberg et al. 1998), and recently it has been shown to infect and kill Formosan subterranean termites Coptotermes formosanus (Shiraki) (Wright et al. pending). Other soft-bodied insect pests are expected to be controllable by Pf as well. The ability to expand the market to multiple pest control applications is expected to enhance commercial development potential of a given biocontrol product.

Table 2. Comparative ranking of dry rot antagonists by traditional and two-dimensional liquid culture screens (Slininger et al. 1994).

\begin{tabular}{|c|c|c|}
\hline \multirow[b]{2}{*}{$\begin{array}{l}\text { Isolate } \\
\text { (NRRL-) }\end{array}$} & \multicolumn{2}{|c|}{$\operatorname{Rank}(1=$ best to $18=$ worst $)$} \\
\hline & $\begin{array}{l}\text { Two-dimensional screen } \\
\text { of efficacy and kinetics } \\
\text { of liquid culture-grown } \\
\text { antagonists }\end{array}$ & $\begin{array}{c}\text { Traditional screen } \\
\text { of efficacy of } \\
\text { agar-grown } \\
\text { antagonists }\end{array}$ \\
\hline B-21050 & 1 & 18 \\
\hline B-21128 & 2 & 13 \\
\hline B-21133 & 3 & 11 \\
\hline B-21134 & 4 & 15 \\
\hline B-21132 & 5 & 14 \\
\hline B-21102 & 6 & 16 \\
\hline B-21136 & 7 & 8 \\
\hline B-21101 & 8 & 11 \\
\hline B-21103 & 9 & 5 \\
\hline B-21053 & 10 & 6 \\
\hline B-21135 & 11 & 17 \\
\hline B-21129 & 12 & 8 \\
\hline B-21104 & 13 & 4 \\
\hline B-21048 & 14 & 1 \\
\hline B-21137 & 15 & 6 \\
\hline B-21051 & 16 & 1 \\
\hline B-21105 & 17 & 10 \\
\hline B-21049 & 18 & 1 \\
\hline
\end{tabular}

\section{Designing the Production Process}

The industrial infrastructure for submerged culture fermentation is so well developed that initial strain selection based on amenability to liquid cultivation followed by strainspecific optimization of the fermentation process are key steps to efficient commercialization of biocontrol agents. For example, in the U.S. Collego ${ }^{\circledR}$ (Colletotrichum gloeosporioides) for the control of northern jointvetch in rice fields and DeVine ${ }^{\circledR}$ (Phytophthora palmivora) for the control of strangler vine in Florida citrus groves are the only bioherbicides marketed in the U.S. Both of these biocontrol agents are amenable to industrial scale submerged cultivation. For each strain of interest, the liquid culture production process must be designed to minimize cost and maximize product yield, production rate and quality. Quality factors to optimize include biocontrol efficacy, storage stability, and host compatibility. Very little research has been published concerning the impact of liquid culture conditions (carbon and nitrogen sources, carbonto-nitrogen ratio, nutrients, temperature, $\mathrm{pH}$, dissolved oxygen), microbial physiology (growth state) and metabolites on the qualities of the biocontrol product, yet these relationships are fundamental to designing the production processes. To illustrate this, key findings of our research on this subject will be reviewed for a variety of biological control agents under development.

Colletotrichm truncatum Mycoherbicide to Control Hemp Sesbania (Sesbania exaltata) in Cotton, Rice and Soybeans. Two nutritional factors, carbon and carbon-to-nitrogen (CN) ratio, were shown to have a dramatic impact on propagule formation by submerged cultures of $C$. truncatum studied using a defined synthetic medium. The $\mathrm{CN}$ ratio of the growth medium was shown to dramatically effect spore yield. Media with $\mathrm{CN}$ ratio of 30:1 consistently produced more conidia than media with $C: N 10: 1$ or $80: 1$. Conidia produced in a medium with $C: N$ 10:1 were longer and thinner than those produced in 30:1 or 80:1 media, and they also germinated more rapidly, formed appressoria more frequently, and incited more disease in hemp sesbania seedlings (Fig 5, Table 3). Rapidly germinating spores are believed to have a significant advantage in causing infection under field conditions where limited freemoisture represents a major constraint to biocontrol efficacy. A CN ratio of 15-20:1 allowed optimal accumulation (1-3 x $10^{7}$ conidia/ml) of the highly efficacious spore type. These $\mathrm{CN}$ ratio studies demonstrated that nutrition impacts not only spore production but also spore quality and biocontrol efficacy. Carbon concentration was also shown to regulate conidiation and microsclerotia formation. High concentrations of conidia were produced when $C$. truncatum cultures were grown in media with a carbon concentration of 4-16 g/L. Carbon concentrations greater than $25 \mathrm{~g} / \mathrm{L}$ halted conidiation and promoted the formation of highly melanized hyphal aggregates which appear to be microsclerotia (Fig. 6). The ability to divert the culture to microsclerotia production by raising the carbon concentration above $25 \mathrm{~g} / \mathrm{L}$ is significant from the standpoint that microsclerotia were stable to storage for more than 48 months and were able to produce infective spores (Jackson et al. 1996, Jackson 1997, Wraight et al. 2001).

Paecilomyces fumosoroseus (Pf) Mycoinsecticide to Control Silver Leaf Whitefly (Bemisia argentifolii). Pf is an effective fungal pathogen for use in biological control of whiteflies (Fig.7). Pf, like many other entomopathogens, grows filamentously and conidiates on solid substrates but grows yeast-like in liquid culture. The yeast-like habit of Pf in liquid culture leads to the rapid production of blastospores, or hyphal bodies, which are very similar to the organism's 
mode of growth in the insect hemolymph. The blastospores produced by various entomopathogens, including Paecilomyces spp., are highly infective structures but are also ephemeral and intolerant to drying. Therefore, our goal in optimizing nutritional conditions for the production of Pf focused on blastospore yield and tolerance to desiccation. In synthetic media studies, an organic nitrogen source was required for adequate growth of Pf. Highest concentrations
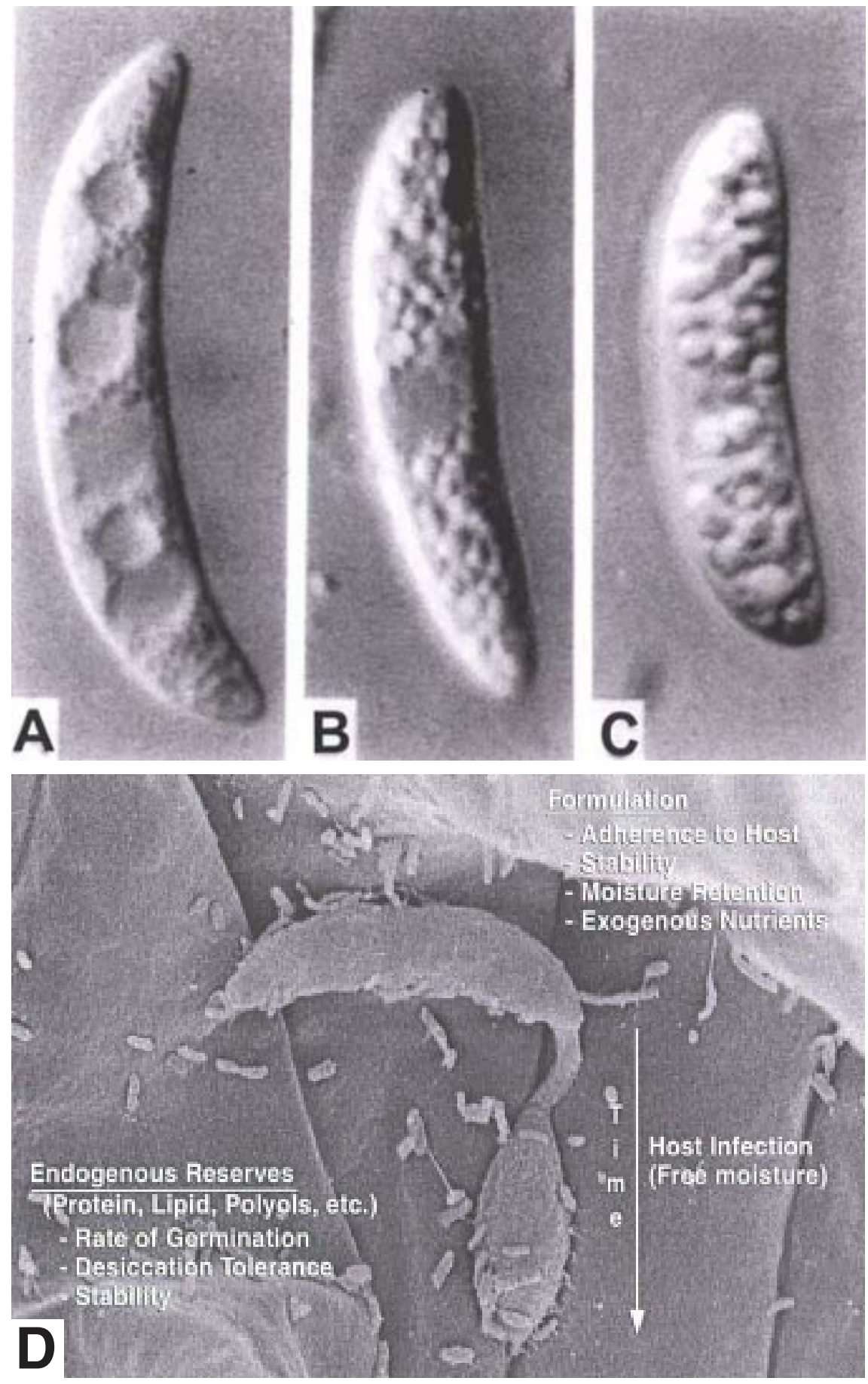

Figure 5. Photomicrographs of C. truncatum conidia produced in submerged culture on media with C:N of A. 10:1, B. 30:1, and C. 80:1. Spores produced in media which promoted lipid synthesis (30:1 and 80:1) contained numerous highly refractile spheres and were less virulent than those produced in 10:1 C:N media which promoted higher protein content (Jackson \& Schisler 1992). D. Scanning electron micrograph of a germinating conidium forming an appressorium (penetration structure) on the root of the weed hemp sesbania (photo provided by D.A. Schisler). The free moisture requirement for spore germination and host penetration is a major constraint to host infection, which can be enhanced by optimizing nutrition and formulation (Jackson 1997). 
Table 3. Influence of $\mathrm{CN}$ ratio on $\mathrm{C}$. truncatum conidial efficacy in inciting disease in S. exaltata seedlings (Jackson \& Schisler 1992).

\begin{tabular}{|c|c|c|}
\hline $\mathrm{CN}$ ratio & $\begin{array}{l}\mathrm{N}^{\mathrm{o}} \text { of leaves/ } \\
\text { seedling }\end{array}$ & $\begin{array}{c}\text { Shoot dry } \\
\text { weight }(\mathrm{mg})\end{array}$ \\
\hline $30: 1$ & 3.4 & 52 \\
\hline $25: 1$ & 2.9 & 45 \\
\hline $20: 1$ & 3.0 & 42 \\
\hline $15: 1$ & 3.1 & 47 \\
\hline $10: 1$ & 2.5 & 36 \\
\hline Control $^{1}$ & 4.7 & 74 \\
\hline \multicolumn{3}{|l|}{$\mathrm{LSD}^{2}$} \\
\hline $\mathrm{P}<0.05$ & 0.30 & 6.0 \\
\hline $\mathrm{P}<0.01$ & 0.40 & 8.0 \\
\hline
\end{tabular}

${ }^{1}$ Control seedlings were sprayed with a heat-killed mixture of conidia produced at each $\mathrm{CN}$ ratio.

${ }^{2} \mathrm{LSD}$, least significant difference

of blastospores $\left(5-10 \times 10^{8} / \mathrm{ml}\right)$ were produced under nutritional conditions where glucose was provided at $>20 \mathrm{~g} /$ L. While production of blastospores occurred under various nutritional conditions, desiccation tolerance required appropriate nitrogen concentrations. Desiccation tolerant blastospores (80\% survival after air- or freeze-drying) of Pf were only produced in media containing between 13 and 40 $\mathrm{g} / \mathrm{L}$ casamino acids (1-3 g nitrogen/L) (Table 4). So, desiccation tolerant blastospores could be rapidly produced (40h) under appropriate nutritional conditions, alleviating critical constraints to their commercial use. Blastospores of Pf have also germinated significantly faster than conidia, and culture nutrition is expected to influence their germination rate and likely infectivity (Jackson 1997, Jackson et al. 1997).

\section{Pseudomonas fluorescens Bacterial Antagonist of Wheat} Take-all Disease [Gaemannomyces graminis var. tritici (Ggt)]. When strain P. fluorescens 2-79 is efficiently delivered to the field in seed coatings, it colonizes the emerging root and produces the antibiotic, phenazine-1-carboxylic acid (PCA), as its primary means of disease suppression. Our research has shown that metabolites (primarily PCA) present in liquid cultures of strain 2-79 cause significant germination losses (up to $64 \%$ ) when included in seed coatings. In mass production of seed inocula, complete separation of cells from metabolites adds considerable expense and may not be feasible if metabolites are insoluble. For P. fluorescens 2-79, the phytotoxicity of the cell harvest can jeopardize the most economical method of application of the biocontrol agent, which is as a wheat seed coating. Our research showed that controlling fermentor environment allowed dramatic reduction of phytotoxic metabolite production. Fermentation conditions, such as dissolved oxygen, carbon source, $\mathrm{pH}$ or temperature, were controlled to allow production of a phytotoxin-free culture broth. This culture could be used directly to treat seeds without sacrifice to either seed germination or to PCA production and take-all disease control in the rhizosphere (Slininger \& SheaWilbur 1995; Slininger et al. 1997b, 1998).

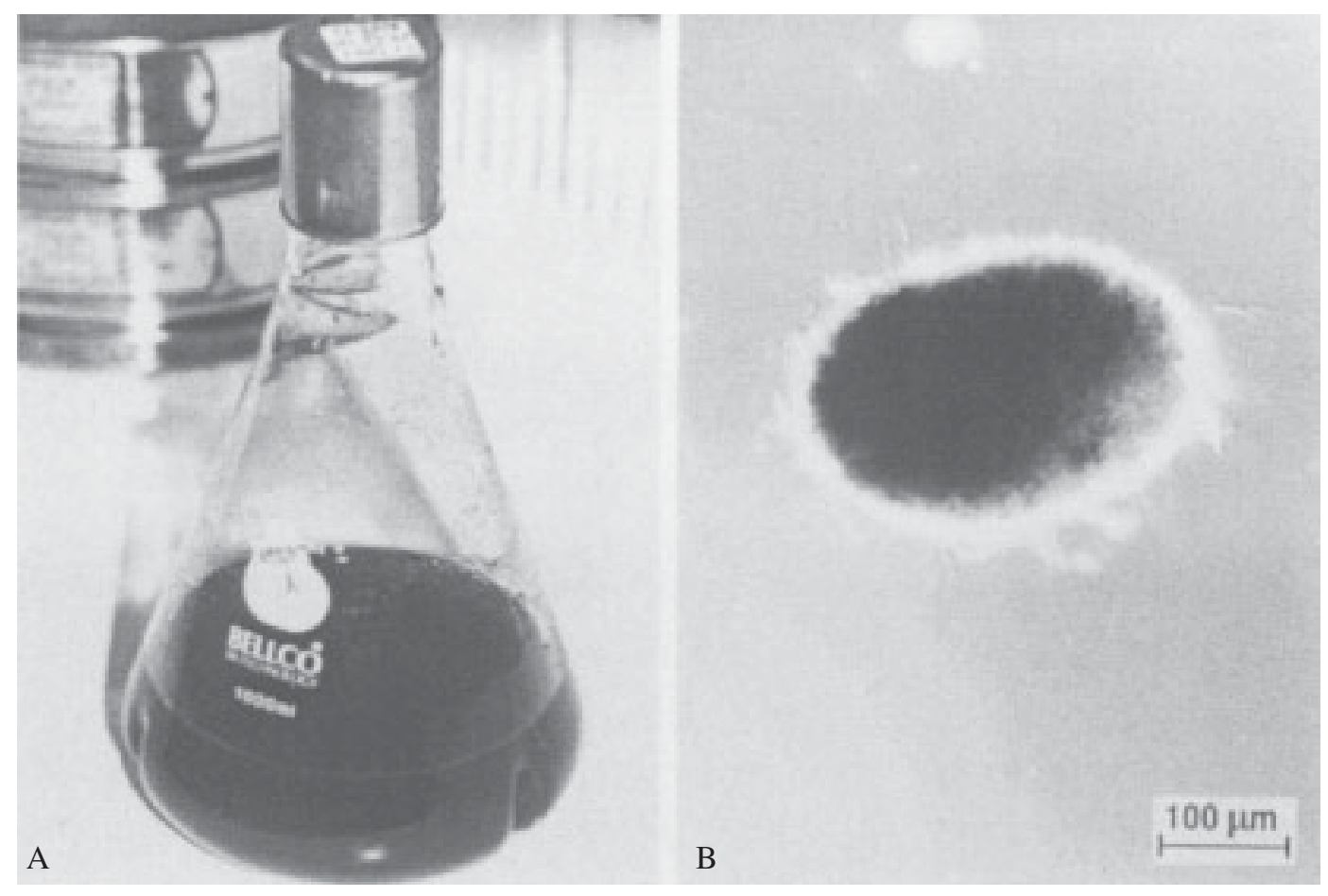

Figure 6. A. Production of microsclerotia of $C$. truncatum in liquid cultures provided $>25 \mathrm{~g} / \mathrm{L}$ carbon. B. Photomicrograph of $C$. truncatum reveals that these particles are highly melanized compact hyphal aggregates, which are approximately 200-400 $\mu \mathrm{m}$ in size (Jackson 1997). 

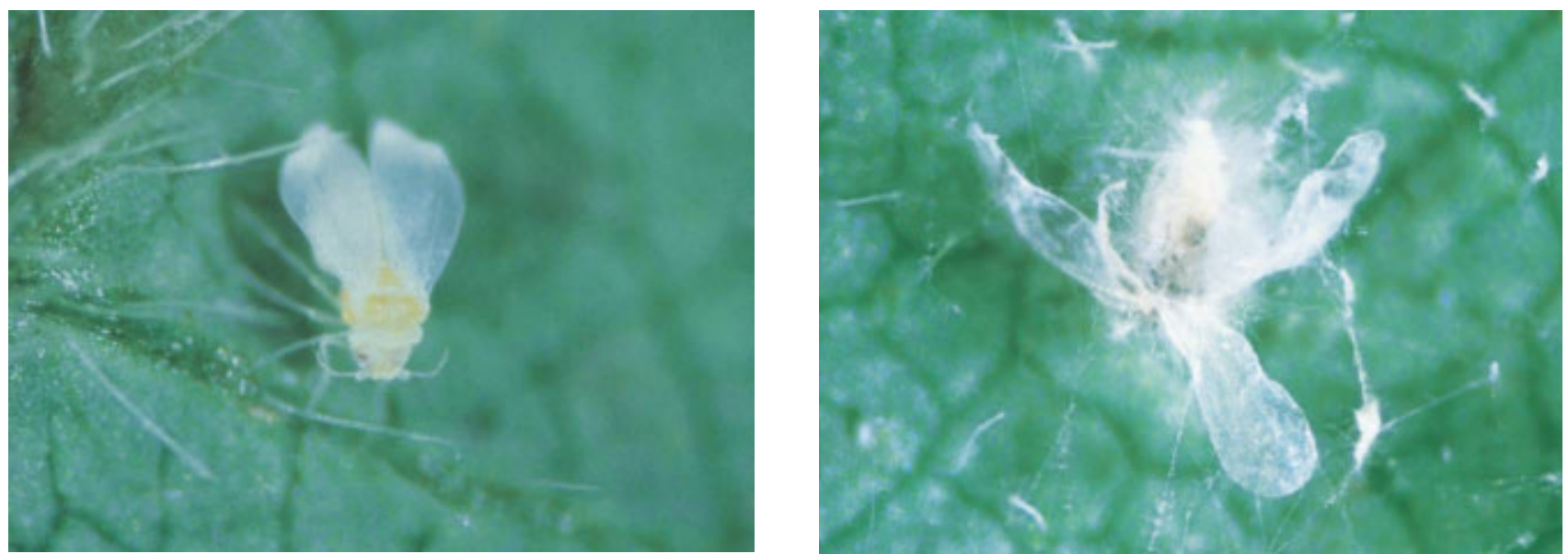

Figure 7. A. Healthy, adult greenhouse whitefly (ca. $1.6 \mathrm{~mm}$ long). B. Whitefly killed by the fungus $P$. fumosoroseus. Spores attach to and penetrate through the insect cuticle. The fungus grows in a yeast-like fashion in the insect hemolymph consuming nutrients, and ultimately, killing the whitefly. Mycelia erupt from the insect cuticle and produce spores on the cadaver which can infect other whiteflies (Jackson 2000).

The physiological state of cells upon harvest from the fermentation process was another factor that has been observed to influence the drying survival and shelf-life of strain 2-79 cells coated in $0.5 \%$ methylcellulose onto wheat seeds. Cells harvested from growth phase cultures survived the drying process better than cells from stationary phase cultures, but stationary phase cells had a longer shelf-life than did growth phase cells. Our data suggest that the protective effect of residual sugar still present in growing cultures may explain why growth phase cells exhibited better survival of the drying process than did stationary cells that were deplete of sugar. The longer shelf-life of the stationary phase cells may come about via one or more of a variety of mechanisms that occur as a result of cell starvation and aging (Slininger et al. 1996, 1998).

\section{Formulating for Storage Stability, Delivery, Host Compatibility and Efficacy}

Once the microbial biological control agent is harvested from the production culture, it will be necessary to formulate it. Formulations can be designed to meet a variety of objectives: to prevent biocontrol agent activity losses during storage; to facilitate convenient and efficacious delivery of the agent to the area where biocontrol is needed; to promote insect biocontrol agent or plant-biocontrol agent compatibility; and to enhance the effectiveness of the biocontrol agent delivered. Examples are reviewed to illustrate formulation techniques devised by our research group to accomplish each of these goals for specific biocontrol problems.

Table 4. Influence of casamino acid concentration on blastospore yield and desiccation tolerance in cultures of $P$.

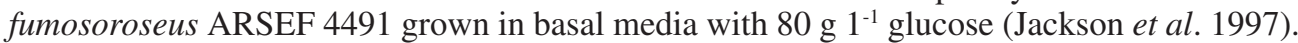

\begin{tabular}{|c|c|c|c|}
\hline $\begin{array}{l}\text { Casamino acids } \\
\left(\mathrm{g} \mathrm{l}^{-1}\right)\end{array}$ & 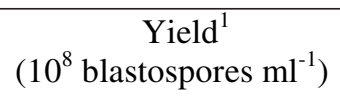 & $\begin{array}{c}\text { Air-drying }^{2} \\
\text { (\% germination) }\end{array}$ & $\begin{array}{c}\text { Viable spores after air-drying } \\
\left(10^{8} \text { blastospores } \mathrm{m}^{-1}\right)\end{array}$ \\
\hline 5 & 3.4 & 6 & 0.2 \\
\hline 10 & 4.4 & 31 & 1.3 \\
\hline 15 & 5.8 & 68 & 3.9 \\
\hline 20 & 7.2 & 80 & 5.8 \\
\hline 25 & 8.9 & 68 & 6.1 \\
\hline 30 & 7.3 & 71 & 5.2 \\
\hline 40 & 6.4 & 56 & 3.9 \\
\hline 50 & 0.3 & $\mathrm{ND}^{3}$ & ND \\
\hline $\begin{array}{l}\text { FPLSD }^{4} \\
(\mathrm{P}<0.05)\end{array}$ & 2.4 & 14 & 2.2 \\
\hline
\end{tabular}

${ }^{1}$ Blastospores collected from 4-day-old cultures

${ }^{2}$ Viability determined by $6 \mathrm{~h}$ germination assay in potato dextrose broth for air-dried blastospores.

${ }^{3}$ Not done. Too few spores were produced to conduct air-drying.

${ }^{4}$ Fisher's protected least significant difference 
Storage Stability. The loss of microbial viability during storage is one of the most challenging barriers to overcome, especially for strains that do not form a resilient spore. Formulation matrices can play an important role in improving storage survival. For example, in the case of $P$. fumosoroseus blastospores, calcined kaolin clay allowed significantly better drying survival and storage stability than other matrices tested (diatomaceous earth, talcs, corn starch, rice flour, and Mexican lime). Greater than $70 \%$ survival was retained after air drying and storage 42 days at $4{ }^{\circ} \mathrm{C}$, and near $20 \%$ after 21 days at $28^{\circ} \mathrm{C}$ was retained using 5\% clay (Sandoval-Coronado et al. 2001). The trend of longer term storage survival with decreasing storage temperature has also held true for liquid formulations of $P$. fluorescens and Enterobacter cloacae, our gram-negative bacterial biocontrol agents of potato dry rot and sprouting; cells frozen at $-20^{\circ} \mathrm{C}$ in neutral buffer exhibited half-lives of 72-161days, while those refrigerated at $4^{\circ} \mathrm{C}$ had half-lives of only 12-33 days (Slininger et al. 1997a). Another general finding of our work has been that the inclusion of culture broth with cells in stored formulations is often, but not always, detrimental to long term cell survival. For example, our gramnegative biocontrol agents for potatoes exhibited half-lives of 26-97 days when frozen in their culture broth and half-lives of 12-42 days when refrigerated in their culture broth. Thus, when frozen, the cells formulated in culture broth had poorer survival than cells in buffer, but when refrigerated, cell survival was similar in culture broth and buffer. When P. fluorescens 2-79 was stored refrigerated in dried methylcellulose coatings of wheat seeds, the culture broth was again observed to be detrimental to drying and long-term cell survival, but the presence of glucose in methylcellulose coatings with culture broth reduced cell losses upon drying (Slininger et al. 1996). These examples illustrate the impact of formulation and storage conditions on biocontrol agent preservation and suggest both the aptitude and need for technology advancement in this area.

Delivery. When biopesticides are applied in the field, the microbial agent is subject to environmental conditions that can no longer be controlled. Detrimental environmental conditions include sunlight, adverse moisture (dry or wet), plant characteristics such as leaf chemistry, and microbial growth of competing organisms. Loss of activity in the field can be minimized through appropriate formulation technology. For example, commercial adjuvants such as Orzan LS and unconventional additives like skim milk were shown to improve the persistence of baculovirus applications (Jackson et al. 1996, Behle et al. 1999). Generally, sunlight is considered the most detrimental factor in reducing bioactivity of aerial biocontrol agent applications to field crops. Loss of insecticidal activity due to sunlight exposure has been demonstrated for bacterial (Gillespie et al. 1994, Hughes et al. 1997), viral (Shapiro \& Argauer 1997), and fungal (Yu \& Brown 1997) biopesticides. Many bioinsecticide adjuvants have been developed to combat the loss of activity due to exposure to sunlight.

Often times the physical circumstances of the delivery can allow the biocontrol agent to be sheltered from UV rays. When granules are applied over a corn plant, the whorl of the plant can act to funnel granules to the preferred feeding sight of the larvae. Light measurements showed that little light is able to penetrate to this location. Granule and sprayable starch-based formulations of Bacillus thuringiensis were developed to entice feeding in order to attract insects to the specific whorl locations and to compensate for Bt being distasteful to insects (McGuire et al. 2000). Additives to the cornstarch-based granular formulation allowed a 75\% reduction in the amount of $\mathrm{Bt}$ applied without loss of efficacy (McGuire \& Shasha 1995). Additives (such as starch, flour, and oil) not only provide shelter from UV rays, but also enhance palatability and reduce washoff during rainfalls. Another novel UV management technique is known as autodissemination. This method uses an attractant that lures adult insects to a device where the insect becomes coated with microbial biocontrol agent and then exits the device to mate and lay eggs. Emerging larvae become infected shortly after hatching and die before causing significant crop damage. Yu \& Brown (1997) demonstrated that the formulation of the active agent affected efficacy and that talc dust performed better than chalk dust, corn starch, flours, alphacel or carbon powder.

Many UV screening compounds have been tested for protecting baculovirus from degradation, but most of these, including stilbene derivatives (such as laundry detergent brighteners), were not cost effective in sprays because of the dilution effect (Behle et al. 1999). Recent research has shown that baculoviruses can be microencapsulated with low-cost lignin to make a bioinsecticide that is more resistant to UV, and retains over $50 \%$ of the original activity for three days after application (McGuire et al. 2001) (Fig. 8). Lignin, which strongly absorbs UV light, is soluble only under alkaline conditions, and so does not dissociate from the biological control agent in the tank; but an alkaline insect gut can dissolve and release the virus.

Recent data suggest that the presence of allelochemicals on a substrate (e.g., insect cuticle or leaf) may be a constraint to the survival of entomopathogenic fungi in the field. Germination of blastospores of the entomopathogenic fungus P. fumosoroseus on Noble agar amended with catechol, salicylic acid, or tannic acid at $500 \mathrm{ppm}$ was half that of blastospores on unamended Noble agar (Vega et al. 1997), and this finding is expected to impact formulation design strategies, again suggesting, for example, the utility of a protective microencapsulation approach to allow effective delivery of the agent.

Efficacy and Host Compatibility. The biocontrol agent $P$. fluorescens 2-79 produces the antifungal compound PCA, which inhibits wheat root colonization by fungal pathogens. Biocontrol agents for controlling root diseases are most efficiently applied as seed inocula. In previous studies, large concentrations of PCA retained with the biocontrol agent culture in methylcellulose seed coatings resulted in large germination losses. One approach to the problem was to eliminate the PCA from the seed coating either by designing the biocontrol agent cultivation to prevent PCA accumulation or by centrifuging cultures of strain 2-79 to isolate the cells only for further use. Formulations safely retaining beneficial antibiotics accumulated in the biocontrol agent production culture have recently been designed. In dual coat formulations, seeds were first coated with a layer of methylcellulose and 

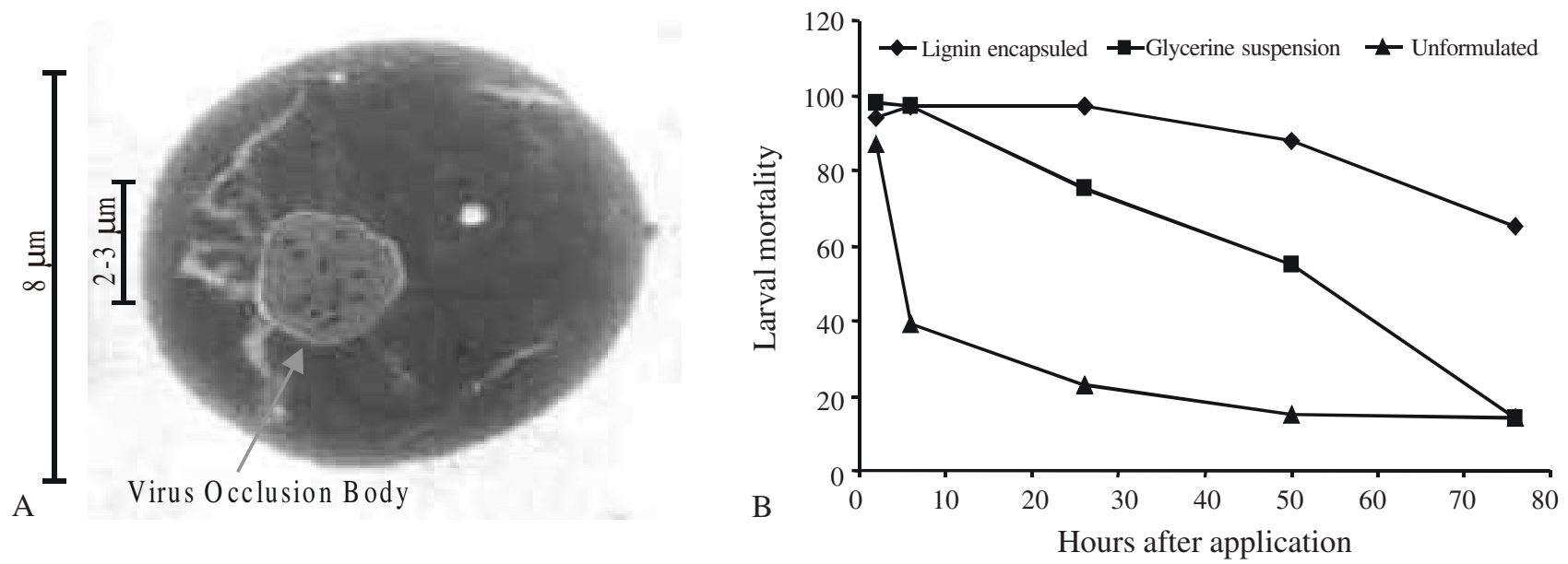

Figure 8. A. Transmission electron micrograph of a baculovirus that is microencapsulated in lignin. The baculovirus occlusion body is about $2-3 \mu \mathrm{m}$ diameter, and the particle is about $8 \mu \mathrm{m}$ diameter (Behle et al. 1999). B. Residual activity based on percentage mortality of cabbage looper Trichoplusia ni when placed on cabbage leaves harvested after application of virus AfMNPV formulations at $2.5 \times 10^{12} \mathrm{PIB} /$ ha in $234 \mathrm{~L} /$ ha to field-grown cabbage plants (McGuire et al. 2001).

then, a second time with a layer containing activated charcoal in methylcellulose-amended culture broth. Using this technique, the antibiotic adsorbed to the charcoal and was trapped on the seed surface to result in a formulation with the following benefits: the convenience of applying the whole biocontrol agent culture without seed germination loss; early protection of the seed from disease by the presence of disease suppressive antibiotic produced during the biocontrol agent cultivation; and the prolonged shelf-life and enhanced efficacy of the seed inoculant following six months storage at $4^{\circ} \mathrm{C}$ (Slininger \& Shea-Wilbur, unpublished).

In addition to taking advantage of antibiotic effects to improve efficacy, another formulation strategy is to modify the nutritional and/or storage environment of the biocontrol agent in order to promote the abundance and speed of outgrowth following application. For example, when microsclerotia of $C$. truncatum germinate, they produce conidia which infect seedlings of the weed hemp sesbania at or near the soil line (Schisler \& Jackson 1996). Flour-based formulations which enhance spore production by $C$. truncatum microsclerotia have been shown to incite higher levels of disease in hemp sesbania seedlings than starch- or starch-flour-based formulations (Jackson et al. 1996).

Achieving consistent efficacy at each application represents a key advancement toward commercialization of a biocontrol product. In recent laboratory and field trials, we have observed that formulations containing multiple strains of our dry rot antagonists performed more consistently than individual strains did when subjected to 32 storage environments varying in potato cultivar, harvest year, potato washing procedure (microflora exposure), temperature, and storage time (Slininger et al. 2001). Successful biocontrol strain mixtures contained both $E$. cloacae and $P$. fluorescens. These strains are known to differ from one another in their range of antibiotic production, substrate utilization, and growth temperature optima. They are also known to differ from one another in ability to suppress disease on various potato cultivars and when incited by various strains of the pathogen $G$. pulicaris (Schisler et al. 2000). The variety of characteristics possessed by the individuals in the successful mixtures suggests that the strain mixtures are likely to be more resilient and more apt to provide individuals amenable to colonize potato wounds despite the variety of environments and pathogen strains encountered. In previous experiments we have also shown that certain strain pairs applied in combination allow greater dry rot suppression than do individual strains (Schisler et al. 1997). Thus, the formulation of strain mixtures has the potential to provide better, more consistent disease control than single strain formulations.

\section{Concluding Remarks}

The future of microbial biological control agents is bright but depends on technological advancements and market opportunities. Commercial interest and user acceptance of biological control agents as pest management tools is dependent on the development of low-cost, stable products which provide consistent efficacy. Solutions to key technical problems and implementation of optimization and design strategies will require research contributions from a variety of disciplines, including weed science, plant pathology, entomology, insect pathology, microbiology, biochemical engineering, biochemistry, and formulation science. International academic, industrial, and government scientists must all work together so that significant advances in the commercialization of biological control agents can be realized.

\section{Acknowledgments}

We would like to express our appreciation to the Entomological Society of Brazil and the organizers of the XIX Brazilian Congress of Entomology held in Manaus, Brazil on June16-21, 2002 for inviting and financially 
supporting the presentation of this work at the Congress. We would also like to thank Dr. Antônio R. Panizzi and the Labex cooperative research program between Embrapa of Brazil and the Agricultural Research Service of the United States Department of Agriculture for making the journey to Brazil possible and so rewarding.

\section{Literature Cited}

Behle, R.W., P. Tamez-Guerra, B.S. Shasha \& M.R. McGuire. 1999. Formulating bioinsecticides to improve residual activity. Proceedings of the Formulations Forum '99, March 3-5, Orlando, FL USA, www.afc-us.org/ papers/1999papers/abehl.htm.

Chelkowski, J. 1989. Toxinogenicity of Fusarium species causing dry rot of potato tubers, p. 435-440. In J. Chelkowski (ed.), Fusarium mycotoxins, taxonomy and pathogenicity. Elsevier, New York, 492p.

Gillespie, R.L., M.R. McGuire \& B.S. Shasha. 1994. Palatability of flour granular formulations to European corn borer larvae (Lepidoptera: Pyralidae). J. Econ. Entomol. 87: 452-457.

Hughes, P.R., H.A. Wood, J.P. Breen, S.F. Simpson, A.J. Duggan \& J.A. Dybas. 1997. Enhanced bioactivity of recombinant baculoviruses expressing insect specific spider toxins in lepidopteran crop pests. J. Invertebr. Pathol. 69: 112-118.

Jackson, M.A. 1997. Optimizing nutritional conditions for the liquid culture production of effective fungal biological control agents. J. Ind. Microbiol. Biotechnol. 19: 180187.

Jackson, M.A. 2000. Microbial biopesticides, p. 541-555. In J. Lederberg (ed.), Encyclopedia of microbiology, $2^{\text {nd }}$ edition, Vol. 1. Academic Press, San Diego, 907p.

Jackson, M.A., B.S. Shasha \& D.A. Schisler. 1996. Formulation of Colletotrichum truncatum microsclerotia for improved biocontrol of the weed hemp sesbania (Sesbania exaltata). Biol. Contr. 7: 107-113.

Jackson, M.A. \& D.A. Schisler. 1992. The composition and attributes of Colletotrichum truncatum spores are altered by the nutritional environment. Appl. Environ. Microbiol. 58: $2260-2265$.

Jackson, M.A., D.A. Schisler, P.J. Slininger, C.D. Boyette, R.W. Silman \& R.J. Bothast. 1996. Fermentation strategies for improving the fitness of a bioherbicide. Weed Technol. 10: 645-650.

Jackson, M.A., M.R. McGuire, L.A. Lacey \& S.P. Wraight. 1997. Liquid culture production of desiccation tolerant blastospores of the bioinsecticidal fungus Paecilomyces fumosoroseus. Mycol. Res. 101: 35-41.
McGuire, M.R. \& B.S. Shasha. 1995. Starch encapsulation of microbial pesticides, p. 229-237. In F.R. Hall \& J.W. Barry (eds.), Biorational pest control agents: formulation and delivery. ACS Symposium Series No. 595, 306p.

McGuire, M.R., P. Tamez-Guerra, R.W. Behle \& D. A. Streett. 2001. Comparative field stability of selected entomopathogenic virus formulations. Biol. Microbial Control 94: 1037-1044.

McGuire, M.R., W.J. Connick \& P.C. Quimby. 2000. Formulation of microbial pesticides, p. 173-198. In H.B. Scher (ed.), Controlled release pesticides. CRC Press, Boca Raton, 205p.

Medugno, C.C., J.M.G. Ferraz, A.H.N. Maia \& D.L. Freitas. 1997. Evaluation of a wettable powder formulation for the nuclear polyhedrosis virus of Anticarsia gemmatalis (Lep.:Noctuidae). Pestic. Sci. 51: 153-156.

Sandoval-Coronado, C.F., H.A. Luna-Olvera, K. ArevaloNino, M.A. Jackson, T.J. Poprawski \& L.J. GalanWong. 2001. Drying and formulation of blastospores of Paecilomyces fumosoroseus (Hyphomycetes) produced in two different liquid media. World J. Microbiol.Biotechnol. 17: 423-428.

Schisler, D.A., K.D. Burkhead, P.J. Slininger \& R.J. Bothast. 1998. Selection, characterization, and use of microbial antagonists for the control of Fusarium dry rot of potatoes, p. 199-221. In G.J. Boland \& L.D. Kuykendall (eds.), Plant-microbe interactions and biological control. Marcel Dekker, Inc., New York, $442 \mathrm{p}$.

Schisler, D.A. \& M.A. Jackson. 1996. Germination of soilincorporated microsclerotia of Colletotrichum truncatum and colonization of seedlings of the weed Sesbania exaltata. Can. J. Microbiol. 42: 1032-1038.

Schisler, D.A. \& P.J. Slininger. 1994. Selection and performance of bacterial strains for biologically controlling Fusarium dry rot of potatoes incited by Gibberella pulicaris. Plant Dis. 78: 251-255.

Schisler, D.A. \& P.J. Slininger. 1997. Microbial selection strategies that enhance the likelihood of developing commercial biological control products. J. Ind. Microbiol. Biotechnol. 19: 172-179.

Schisler, D.A., P.J. Slininger, L.E. Hanson \& R. Loria. 2000. Potato cultivar, pathogen isolate and antagonist cultivation medium influence the efficacy and ranking of bacterial antagonists of Fusarium dry rot. Biocontrol Science and Technology. 10: 267-279.

Schisler, D.A., P.J. Slininger \& R.J. Bothast. 1997. Effects of antagonist cell concentration and two-strain mixtures 
on biological control of Fusarium dry rot of potatoes. Phytopathology 87: 177-183.

Shapiro, M. \& R. Argauer. 1997. Components of the stilbene optical brightener Tinopal LPW as enhancers of the gypsy moth (Lepidoptera: Lymatriidae) baculovirus. J. Econ. Entomol. 90: 899-904.

Slininger, P.J., D.A. Schisler \& G. Kleinkopf. 2001. Combinations of dry rot antagonistic bacteria enhance biological control consistency in stored potatoes. Phytopathology 91: S83.

Slininger, P.J., D.A. Schisler, K.D. Burkhead, R.C. Ostrowski \& R.J. Bothast. 1997a. Development of biological agents for the control of fusarium dry rot disease of stored potatoes. Am. Potato J. 74: 467-468.

Slininger, P.J., D.A. Schisler \& R.J. Bothast. 1994. Twodimensional liquid culture focusing: a method of selecting commercially promising microbial isolates with demonstrated biological control capability, p. 29-32. In M.H. Ryder, P.M. Stephens, \& G.D. Bowen (eds.), Improving plant productivity with rhizosphere bacteria, $3^{\text {rd }}$ International Workshop on Plant Growth-Promoting Rhizobacteria, Adelaide, South Australia. CSIRO Division of Soils, Glen Osmond, South Australia. 288p.

Slininger, P.J., J.E. VanCauwenberge, M.A. Shea-Wilbur, K.D. Burkhead, D.A. Schisler \& R.J. Bothast. 1997b. Reduction of phenazine-1-carboxylic acid accumulation in growth cultures of the biocontrol agent Pseudomonas fluorescens 2-79 eliminates phytotoxic effects of wheat seed inocula without sacrifice to take-all suppressiveness, p. 464-467. In A. Ogoshi, K. Kobayashi, Y. Homma, F. Kodama, N.Kondo \& S. Akino (eds.), Plant growthpromoting rhizobacteria present status and future prospects. The $4^{\text {th }}$ PGPR International Workshop Organizing Committee, Faculty of Agriculture, Hokkaido University, Lab of Plant Pathology, Sapporo, Japan, 483p.

Slininger, P.J., J.E. VanCauwenberge, M.A. Shea-Wilbur \& R.J. Bothast. 1998. Impact of liquid culture physiology, environment, and metabolites on biocontrol agent qualities- Pseudomonas fluorescens 2-79 versus wheat take-all, p. 199-221. In G.J. Boland \& L.D. Kuykendall (eds.), Plant-microbe interactions and biological control. Marcel Dekker, Inc., New York, 442p.

Slininger, P.J., J.E. VanCauwenberge, R.J. Bothast, D.M.
Weller, L.S. Thomashow \& R.J. Cook. 1996. Effect of growth culture physiological state, metabolites, and formulation on the viability, phytotoxicity, and efficacy of the take-all biocontrol agent Pseudomonas fluorescens 2-79 stored encapsulated on wheat seeds. Appl. Microbiol. Biotechnol. 45: 391-398.

Slininger, P.J., K.D. Burkhead, D.A. Schisler \& R.J. Bothast. 2000. Biological control of sprouting in potatoes. United States Patent 6, 107, 247.

Slininger, P.J. \& M.A. Shea-Wilbur. 1995. Liquid-culture $\mathrm{pH}$, temperature, and carbon (not nitrogen) source regulate phenazine productivity of the take-all biocontrol agent Pseudomonas fluorescens 2-79. Appl. Microbiol. Biotechnol. 43: 794-800.

Vandenberg, J.D., M.A. Jackson \& L.A. Lacey. 1998. Relative efficacy of blastospores and aerial conidia of Paecilomyces fumosoroseus against the Russian wheat aphid. J. Invertebr. Pathol. 72: 181-183.

Vega, F.E., P.F. Dowd, M.R. McGuire, M.A. Jackson \& T.C. Nelsen. 1997. In vitro effects of secondary plant compounds on germination of blastospores of the entomopathogenic fungus Paecilomyces fumosoroseus (Deuteromycotina:Hyphomycetes). J. Invertebr. Pathol. 70: 209-213.

Woodhead, S.H., D.J. O'Leary \& S.C. Rabatin. 1990. Discovery, development, and registration of a biocontrol agent from an industrial perspective. Can. J. Plant Pathol. 12: 328-331.

Wraight, S.P., M.A. Jackson \& S.L. DeKock. 2001. Production, stabilization and formulation of fungal biocontrol agents, p. 253-287. In T. Butt, C. Jackson \& N. Magan (eds.), Fungal biocontrol agents-progress, problems, and potential. CAB International, Wallingford, United Kingdom, 390p.

Wright, M.S., M.A. Jackson \& W.J. Connick. (Pending) Use of Paecilomyces spp. as pathogenic agents against subterranean termites. U.S. Patent Application (filed November 20, 2001).

Yu, Z. \& G.C. Brown. 1997. Autodissemination of a beet armyworm (Lepidoptera:Noctuidae) baculovirus under laboratory conditions. J. Econ. Entomol. 90: 1187-1194. 